\title{
Cause specific mortality among employees engaged in the manufacture, formulation, or packaging of 2,4-dichlorophenoxyacetic acid and related salts
}

\author{
G G BOND, N H WETTERSTROEM, G J ROUSH, E A MCLAREN, T E LIPPS, \\ R R COOK
}

From Dow Chemical USA, Epidemiology, $H \&$ ES, Midland, Michigan 48674, USA

ABSTRACT Mortality is reported to the end of 1982 for 878 chemical workers potentially exposed to 2,4-dichlorophenoxyacetic acid (2,4-D) at any time between 1945 and 1983. Observed mortality was compared with expected levels based on adjusted rates for United States white men and for other male employees from this manufacturing location who were not exposed to 2,4-D. Because of a recently reported increased incidence of astrocytomas in male rats fed the highest dose level of 2,4-D, special attention was given to deaths from brain neoplasms in the cohort. None was observed. The absence of an increased risk of brain cancer in people exposed to 2,4-D is supported by studies of other exposed populations and those studies are briefly reviewed. Moreover, in the present study, analyses by production area, duration of exposure, and cumulative dose showed no patterns suggestive of a causal association between 2,4-D exposure and any other particular cause of death.

Herbicides containing 2,4-dichlorophenoxyacetic acid (2,4-D) have been used world wide for weed control in agriculture and forestry since the late 1940s. Recently, a two year dietary study with 2,4-D at targeted dose levels of $0,1,5,15$, or $45 \mathrm{mg} / \mathrm{kg} /$ day in Fischer 344 rats showed a statistically significant increase in the number of astrocytomas in the brains of high dose male rats only (Industry Task Force on 2,4-D research data, unpublished, 1986). No increased incidence of brain tumours was observed in female rats and no unusual incidence of tumours was noted in any other organs. The finding of increased brain tumours has heightened interest in the consequences of exposure to 2,4-D to man.

The Michigan Division of Dow Chemical USA has manufactured and formulated 2,4-D herbicides since 1945. A historical cohort mortality study was then undertaken of the 878 employees who were potentially exposed to 2,4-D between 1945 and 1983 to determine whether or not brain cancer or other causes of death had occurred excessively, and in relation to level of exposure.

Accepted 26 January 1987

\section{Environmental considerations}

Over the years 2,4-D exposure to employees potentially occurred in any of four separate buildings in which 2,4-D was manufactured, esterified, aminated, formulated, or packaged. Initial production of 2,4-D took place in the organic semi plant from 1945 until 1950 and then occurred again intermittently in small amounts in 1967 until 1969. A new plant devoted to full scale 2,4-D production was constructed in 1950. This new plant, referred to as the 2,4-D plant, housed the production of 2,4-D herbicides through both the acid ester and 2,4-D acid process. A direct ester process was brought on-line in 1965. Formulating and packaging of 2,4-D and other phenoxy herbicides such as 2,4,5-T, MCPA, and Silvex, was carried out for many years in the same building. Beginning in 1977, production of 2,4-D acid was moved to the new herbicides plant. Since then molten acid has been sent to the 2,4-D plant for esterification, amination, formulation, and packaging. Formulation of 2,4-D products with picloram has been done in the Tordon* plant since 1964.

Table 1 shows a summary of the available industrial hygiene monitoring data for 2,4-D in these plants. Industrial hygiene studies were conducted in the

*Registered trademark of The Dow Chemical Company. 
Table 1 Summary of industrial hygiene measurements of 2,4-D levels by production area

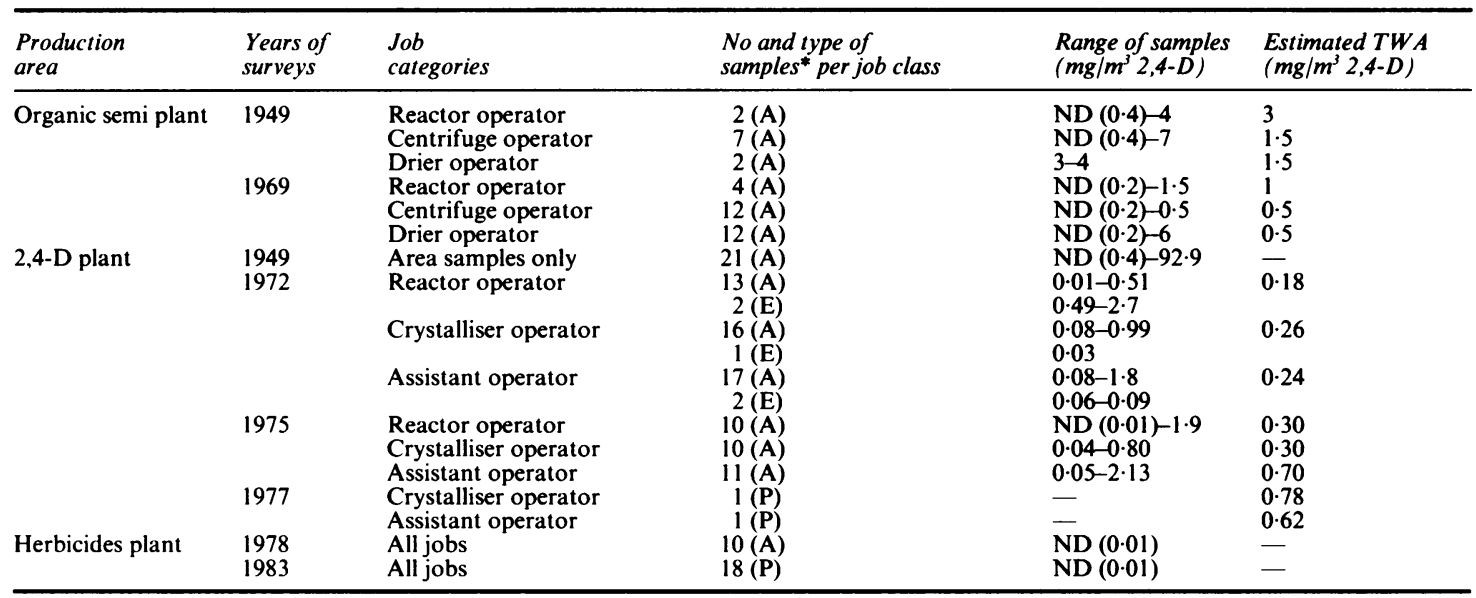

$\mathrm{A}=$ Area sample; $\mathrm{E}=$ excursion sample; $\mathbf{P}=$ personal sample.

Note: Area and excursion samples were both used to estimate time weighted average (TWA) exposures.

ND ( ) = Non-detectable (analytical limit of detection).

organic semi plant in 1949 and 1969, in the 2,4-D plant in 1949, 1972, 1975, and 1977, and in the herbicides plant in 1978 and again in 1983. Two types of sampling/analytical techniques were used with filter collection/gravimetric analysis used before 1969 and midget impingers in series $(0 \cdot 1 \mathrm{~N} \mathrm{NaOH})$ /gas chromatography used thereafter.

Production of 2,4-D was through batch reaction of 2,4-dichlorophenol with monochloroacetic acid in a closed vessel. The excess phenol was stripped, HCL was added for crystal recovery on vacuum wheels, and the damp product was dried. Exposure conditions improved greatly in 1969 with the implementation of engineering controls which enclosed the dryer and provided better ventilation. Although no data were available to quantify 2,4-D exposures in the Tordon ${ }^{\text {it }}$ plant, short relatively high excursion exposures would have occurred from 1964 to 1966 when bags of 2,4-D powder were manually emptied into a formulations tank. Thereafter, 2,4-D liquour was transferred by pipeline, greatly reducing the opportunity for exposure.

\section{Methods and materials}

Employees included in the study cohort were identified from 1945-82 census lists for the four departments described above. These lists represent a cross sectional roster of department employees and were available on an annual basis until 1964, and on a monthly basis thereafter. Work history records were obtained for the 878 employees identified from the census lists, and all jobs involving potential 2,4-D exposure to the end of 1982 were coded and input for data processing.
Lists of jobs by department were given to industrial hygienists who are knowledgeable about exposure conditions in these operations. The hygienists then developed a job-exposure matrix which ranked employee exposures (low, moderate, or high) based on available monitoring data and professional judgment. Exposures for some jobs were noted to have been reduced over time as a result of process improvements and the matrix reflected this. The job-exposure matrix was then match merged to the computerised employee work histories by department, job, and calendar year to assign an exposure level to each of employee job assignments. A cumulative dose was then developed for each employee by multiplying the representative eight hour time weighted average (TWA) exposure value for each job assignment by the number of years the job was held, and then summing the product across all jobs. The TWA value of $0.05 \mathrm{mg} / \mathrm{m}^{3}$ was used for low level, $0.5 \mathrm{mg} / \mathrm{m}^{3}$ for moderate level, and $5 \mathrm{mg} / \mathrm{m}^{3}$ for high level exposure.

The cohort was then linked to a master file containing demographic and vital status information updated to the end of 1982 (Michigan Division vital status registry) and to a mortality register (epidemiology mortality file) to identify causes of death. These files have been designed, assembled, and maintained to facilitate the efficient conduct of such studies. ${ }^{1}$

Analyses were done by production area, duration of exposure, and cumulative dose. Employees may have contributed person-years at risk to several categories of those variables consistent with their time dependency. Allowance was made for possible latent effects of exposure by conducting an analysis which lagged exposures by a fixed interval of 15 years. $^{2}$ 
The mortality experience of the exposed cohort was first compared with that of the United States white male population using rates (USDR 58) and computer software developed by Monson. ${ }^{3}$ Person-years at risk for subjects were accumulated across five year age and calendar year specific intervals beginning with the date of first exposure to 2,4-D until the earliest of the following events: (1) the employee died, (2) the employee was lost to follow up, in which case he was withdrawn alive on the date of last contact, or (3) 31 December 1982. The numbers of expected deaths for 57 cause specific categories were derived by multiplying the age and calendar year specific person-years and mortality rates together and then summing the products across strata. The standardised mortality ratio (SMR) was calculated as the ratio of observed to expected deaths multiplied by 100 . Ninety five per cent confidence limits were calculated using Miettinen's test based method ${ }^{4}$ when the number of observed events exceeded 20 and Fisher's exact probability test ${ }^{5}$ when the observed totalled 20 or fewer. The SMR was judged statistically significant when the confidence limits excluded the null value of 100 . Examination for trends across SMRs was done using a chi squared trend test with one degree of freedom as outlined by Breslow. ${ }^{6}$

To control some of the biases associated with the "healthy worker effect," or with region of residence, a comparison was also made between the study cohort and all other male employees from this company location. This comparison was achieved through direct adjustment of mortality rates using an adaptation of the Mantel-Haenszel method for cohort studies. ${ }^{7}$ Person-years and deaths were categorised by exposure to 2,4-D, and mortality was compared between exposed and unexposed subjects adjusted for age, interval since entry into follow up, and pay status (hourly or salary).

As a consequence of the proximity of 2,4-D operations to 2,4,5-T production and formulation, and the job mobility of employees between units, a substantial percentage of employees in this cohort had the opportunity for exposure to tetra and higher chlorinated dioxins (TCDD or H/OCDDs or both). Analyses were then done stratifying employees according to whether or not they had such additional exposures.

\section{Results}

Table 2 shows the vital and employment status distributions of the 878 cohort members on 31 December 1982 . Follow up was $99.9 \%$ complete as only one employee could not be traced. A total of 111 deaths was identified and certificates were obtained to determine the cause of death for them all.

Table 3 shows the distribution of employees by decade of first exposure and duration of exposure. The median year of first exposure was 1963 , and $58.1 \%$ of employees were first exposed at least 15 years before the closing date of the study. The mean duration of exposure was 3.0 years (median $=1.1$ years). The 878 cohort members contributed 16297 person-years at risk for an average follow up of 18.6 years. The average age at entry into follow up was $28 \cdot 7$ years.

The distribution of cohort members by exposure level, and within each level by decade of first exposure and duration of exposure is shown in table 4 . Improvements in exposure conditions over time and job mobility by employees resulted in some employees having been exposed at more than one intensity level. More than one third of the cohort members were exposed in jobs categorised as $5 \mathrm{mg} / \mathrm{m}^{3}$ TWA exposure and nearly two thirds were exposed in jobs categorised as $0.5 \mathrm{mg} / \mathrm{m}^{3}$ TWA.

Table 5 presents overall mortality comparisons for selected causes of death. The all causes SMR was 100 . There was a non-significant rise in mortality from total malignant neoplasms $(S M R=115)$. There were no deaths coded to brain cancer, brain tumour, or other and unspecified neoplasms of the brain. There was a significant excess of cancer of other and ill defined sites based on five observed cases. A review of the death certificates for those five cases and for all decedents confirmed the absence of brain neoplasms among cohort members. Non-significant excesses were noted for several cancer sites based on a small number of cases, including cancer of the large intestine (4), lymphosarcoma and reticulosarcoma (2), and leukaemia (2). One of the leukaemias was of the acute myelogenous variety in an employee with documented exposure to benzene. ${ }^{8}$ Five employees were killed in work related accidents, three in a 1950 explosion of a latex pilot plant and two from acute chemical exposures (one each from dichlorophenol and phenol).

Analysis of mortality in the cohort was done allowing for a 15 year minimum latency period. This effectively removed from the analysis those exposed after 1967. The mortality patterns described above were not altered, although some of the cause specific SMRs were increased slightly.

Mortality in the cohort was also compared with expected levels based on the experience of unexposed male workers from this manufacturing location $(\mathrm{n}=$ 36804 ; person-years $=921921$ ) adjusted for age, interval since entry, and pay status (hourly, salary). Table 6 lists the Mantel-Haenszel relative risks for major categories of death, the rates for many specific causes of death being too unstable for comparison purposes. No significant differences were noted, although the patterns which were apparent from the comparison with United States men remained evident here as well. 
Table 2 Vital and employment status as of 1 January 1983; study of chemical workers exposed to 2,4-dichlorophenoxyacetic acid and related salts

\begin{tabular}{|c|c|c|c|c|c|}
\hline \multirow[b]{2}{*}{ Employment status } & \multicolumn{5}{|l|}{ Vital status } \\
\hline & $\begin{array}{l}\text { Alive } \\
\text { No }\end{array}$ & $\begin{array}{l}\text { Dead } \\
\text { No }\end{array}$ & $\begin{array}{l}\text { Unknown } \\
\text { No }\end{array}$ & $\begin{array}{l}\text { Total } \\
\text { No }\end{array}$ & $(\%)$ \\
\hline $\begin{array}{l}\text { Continued employment } \\
\text { Retired } \\
\text { Left employment } \\
\text { Died while employed }\end{array}$ & $\begin{array}{r}407 \\
115 \\
244 \\
0\end{array}$ & $\begin{array}{r}0 \\
37 \\
33 \\
41\end{array}$ & $\begin{array}{l}0 \\
0 \\
1 \\
0\end{array}$ & $\begin{array}{r}407 \\
152 \\
278 \\
41\end{array}$ & $\begin{array}{r}(46 \cdot 4) \\
(17 \cdot 3) \\
(31 \cdot 7) \\
(4 \cdot 7)\end{array}$ \\
\hline Total No (\%) & $766(87 \cdot 2)$ & $111(12 \cdot 6)$ & $1(0 \cdot 1)$ & 878 & $(100 \cdot 1)$ \\
\hline
\end{tabular}

Table 3 Distribution of 2,4-D cohort by year of first exposure and duration of exposure

\begin{tabular}{|c|c|c|c|c|c|}
\hline \multirow{2}{*}{$\begin{array}{l}\text { Decade of } \\
\text { first exposure }\end{array}$} & \multicolumn{5}{|c|}{ Duration of exposure (years)* } \\
\hline & $<I$ & $1-4 \cdot 9$ & $5-14.9$ & $\geq 15$ & Total \\
\hline $\begin{array}{l}<1950 \\
1950-9 \\
1960-9 \\
1970-9 \\
\geq 1980 \\
\text { Total }\end{array}$ & $\begin{array}{r}80 \\
57 \\
157 \\
121 \\
15 \\
430\end{array}$ & $\begin{array}{r}90 \\
42 \\
61 \\
105 \\
13 \\
311\end{array}$ & $\begin{array}{r}26 \\
15 \\
24 \\
30 \\
0 \\
95\end{array}$ & $\begin{array}{r}8 \\
25 \\
9 \\
0 \\
0 \\
42\end{array}$ & $\begin{array}{r}204 \\
139 \\
251 \\
256 \\
28 \\
878\end{array}$ \\
\hline
\end{tabular}

*Adjusted for breaks in service and accumulated to the end of 1982.

Table 4 Distribution of 2,4-D cohort* by exposure level and within by decade of first exposure and duration

\begin{tabular}{|c|c|c|c|c|c|c|}
\hline \multirow[b]{2}{*}{ Exposure level } & \multirow{2}{*}{$\begin{array}{l}\text { Decade of } \\
\text { first exposure }\end{array}$} & \multicolumn{5}{|c|}{ Duration (years) $\dagger$} \\
\hline & & $<1$ & $1-4 \cdot 9$ & $5-14 \cdot 9$ & $\geq 15$ & Total \\
\hline High & $\begin{array}{l}\text { Total } \\
<1950 \\
1950-9 \\
1960-9 \\
1970-9 \\
\geq 1980\end{array}$ & $\begin{array}{r}152 \\
63 \\
27 \\
62 \\
0 \\
0\end{array}$ & $\begin{array}{r}117 \\
87 \\
19 \\
11 \\
0 \\
0\end{array}$ & $\begin{array}{r}32 \\
14 \\
14 \\
4 \\
0 \\
0\end{array}$ & $\begin{array}{r}12 \\
2 \\
10 \\
0 \\
0 \\
0\end{array}$ & $\begin{array}{r}313 \\
166 \\
70 \\
77 \\
0 \\
0\end{array}$ \\
\hline Moderate & $\begin{array}{l}\text { Total } \\
<1950 \\
1950-9 \\
1960-9 \\
1970-9 \\
\geq 1980\end{array}$ & $\begin{array}{r}292 \\
42 \\
65 \\
118 \\
54 \\
13\end{array}$ & $\begin{array}{r}154 \\
6 \\
25 \\
34 \\
77 \\
12\end{array}$ & $\begin{array}{r}53 \\
2 \\
12 \\
20 \\
19 \\
0\end{array}$ & $\begin{array}{l}9 \\
1 \\
5 \\
3 \\
0 \\
0\end{array}$ & $\begin{array}{r}508 \\
51 \\
107 \\
175 \\
150 \\
25\end{array}$ \\
\hline Low & $\begin{array}{l}\text { Total } \\
<1950 \\
1950-9 \\
1960-9 \\
1970-9 \\
\geq 1980\end{array}$ & $\begin{array}{r}264 \\
26 \\
31 \\
84 \\
117 \\
6\end{array}$ & $\begin{array}{r}134 \\
23 \\
14 \\
35 \\
59 \\
3\end{array}$ & $\begin{array}{r}33 \\
4 \\
9 \\
4 \\
16 \\
0\end{array}$ & $\begin{array}{l}3 \\
1 \\
2 \\
0 \\
0 \\
0\end{array}$ & $\begin{array}{r}434 \\
54 \\
56 \\
123 \\
192 \\
9\end{array}$ \\
\hline
\end{tabular}

*Employees may have been exposed at more than one level and therefore may be counted multiple times in the table.

†Adjusted for breaks in service and accumulated to the end of 1982.

Analyses were done by production area (table 7) in order to determine whether there might be findings unique to an area and possibly indicative of the effects of an agent other than 2,4-D but also associated with that area. Because the 2,4-D and organic semi plants began operations much earlier, the overwhelming majority of cohort deaths were observed in those two areas. All the lymphopoietic cancers in the cohort occurred in employees who had worked in the 2,4-D plant, and this represented a significant excess over expectation. Cancer of other and unspecified sites was also significantly raised among the subset of employees from that plant. No other significant differences were apparent.

A total of 674 study subjects $(76.8 \%)$ had the opportunity for exposure to TCDD or H/OCDDs or 
Table 5 Observed and expected* deaths, SMR, and 95\% CL for selected causes of death; study of chemical workers exposed to 2,4-D and related salts, $1945-82$

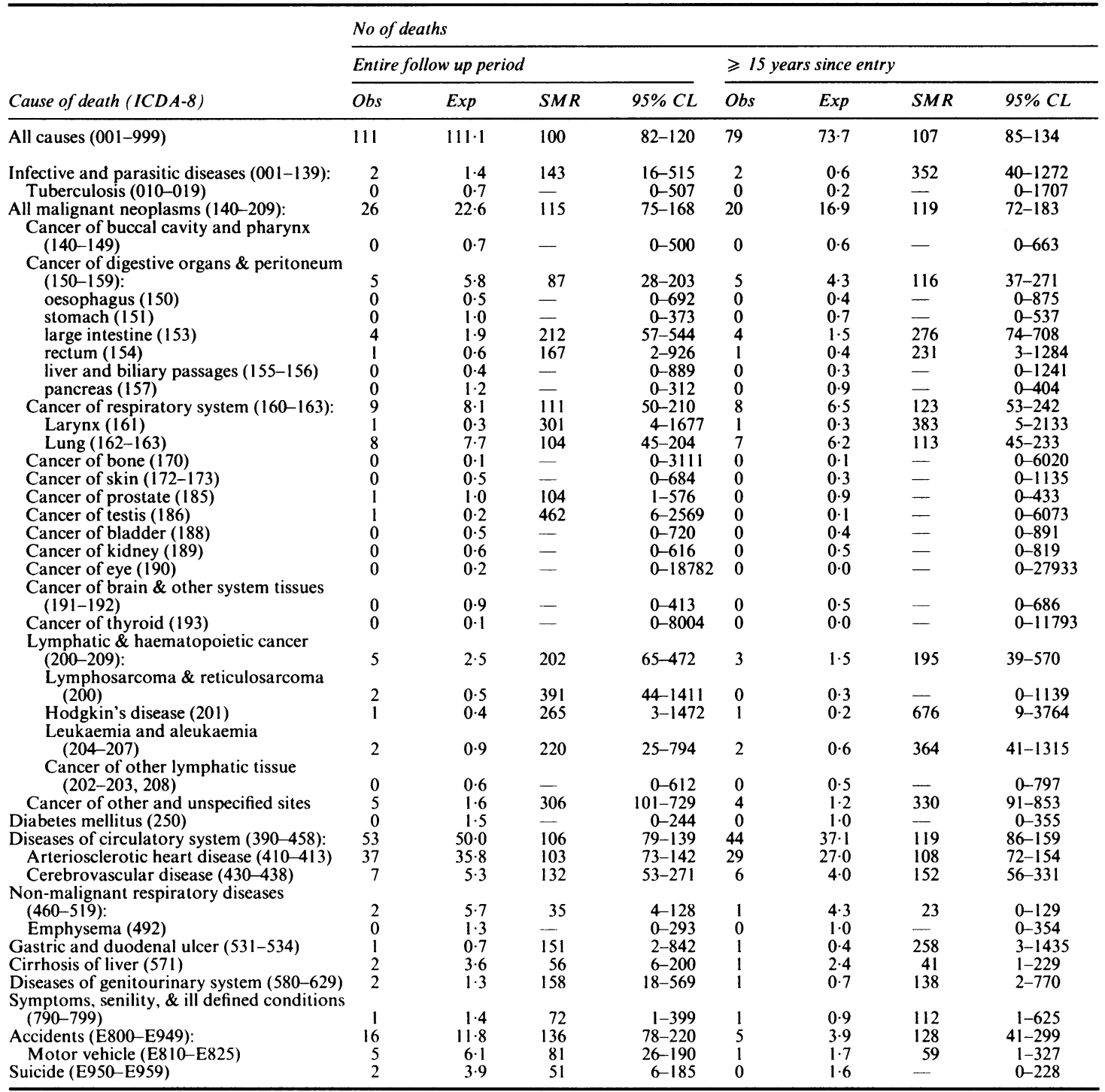

*Number of expected deaths are based on United States white male mortality rates.

$-=$ Inestimable.

both as a consequence of working in close proximity to 2,4,5-T operations or because of other job assignments necessitating direct exposure. An analysis that subdivided employees by whether or not they had the opportunity for those additional exposures did not show any significant differences between the groups.

Table 8 gives the numbers of observed and expected deaths from all malignant neoplasms by duration of exposure and interval since first exposure. There were no significant rises in any subset, nor were there any significant trends with duration or with interval since entry. This was also true for other categories of death.

Table 9 presents the results of dose response analyses for selected causes of death. Person-years and deaths were subdivided into three cumulative dose categories; < $0.5 \mathrm{mg} / \mathrm{m}^{3}$-years, $0.5-4.9 \mathrm{mg} / \mathrm{m}^{3}$-years, 
Table 6 Summary of mortality among 2,4-D cohort relative to unexposed workers from the same manufacturing location

\begin{tabular}{|c|c|c|c|c|c|c|}
\hline \multirow[b]{2}{*}{ Cause of death (ICDA-8) } & \multicolumn{2}{|c|}{ Unexposed to 2,4-D } & \multicolumn{4}{|c|}{ Exposed to 2,4-D } \\
\hline & Obs & $R R \dagger$ & Obs & $\operatorname{Exp}^{*}$ & $R R^{\dagger}$ & $95 \% \mathrm{CI}$ \\
\hline All causes (001-999) & 7640 & 1.00 & 111 & $98 \cdot 2$ & $1 \cdot 13$ & $0.94-1 \cdot 36$ \\
\hline $\begin{array}{l}\text { All malignant neoplasms }(140-209): \\
\text { Digestive system cancer }(150-159) \\
\text { Respiratory system cancer }(160-163) \\
\text { Lymphatic and haematopoietic cancer }\end{array}$ & $\begin{array}{r}1640 \\
424 \\
540\end{array}$ & $\begin{array}{l}1.00 \\
1.00 \\
1.00\end{array}$ & $\begin{array}{r}26 \\
5 \\
9\end{array}$ & $\begin{array}{r}21 \cdot 0 \\
5 \cdot 1 \\
7 \cdot 4\end{array}$ & $\begin{array}{l}1.24 \\
0.99 \\
1.21\end{array}$ & $\begin{array}{l}0.84-1.83 \\
0.41-2.40 \\
0.62-2 \cdot 34\end{array}$ \\
\hline $\begin{array}{l}\text { Cancer of ill defined sites (199) } \\
\text { All circulatory system diseases }(390-458) \text { : } \\
\text { Arteriosclerotic heart disease }(410-413) \\
\text { Cerebrovascular disease (430-438) } \\
\text { Accidents (E800-E949): } \\
\text { Motor vehicle accidents (E810-E825) }\end{array}$ & $\begin{array}{r}193 \\
164 \\
3868 \\
2798 \\
518 \\
572 \\
309\end{array}$ & $\begin{array}{l}1.00 \\
1.00 \\
1.00 \\
1.00 \\
1.00 \\
1.00 \\
1.00\end{array}$ & $\begin{array}{r}5 \\
5 \\
53 \\
37 \\
7 \\
16 \\
5\end{array}$ & $\begin{array}{r}2 \cdot 5 \\
2 \cdot 2 \\
45 \cdot 3 \\
34 \cdot 2 \\
4 \cdot 8 \\
10 \cdot 8 \\
6 \cdot 6\end{array}$ & $\begin{array}{l}2.01 \\
2.32 \\
1.17 \\
1.08 \\
1.47 \\
1.48 \\
0.76\end{array}$ & $\begin{array}{l}0 \cdot 84-4 \cdot 80 \\
0 \cdot 98-5 \cdot 51 \\
0 \cdot 89-1 \cdot 53 \\
0 \cdot 78-1 \cdot 49 \\
0 \cdot 70-3 \cdot 12 \\
0 \cdot 91-2 \cdot 42 \\
0 \cdot 32-1 \cdot 83\end{array}$ \\
\hline
\end{tabular}

*Expected deaths based on mortality rates of unexposed workers adjusted for age, interval since entry, and pay status (hourly, salary).

†Mantel-Haenszel risk relative to unexposed workers.

Table 7 Mortality summary of 2,4-D cohort by production area $\dagger$

\begin{tabular}{|c|c|c|c|c|c|c|c|c|c|c|c|c|}
\hline \multirow[b]{3}{*}{ Cause of death (ICDA-8) } & \multicolumn{12}{|c|}{ Production area } \\
\hline & \multicolumn{3}{|c|}{ 2,4-D plant } & \multicolumn{3}{|c|}{ Organic semi plant } & \multicolumn{3}{|c|}{ Herbicide plant } & \multicolumn{3}{|c|}{ Tordon plant } \\
\hline & Obs & Exp+ & $S M R$ & Obs & Exp $\ddagger$ & $S M R$ & Obs & Exp $\ddagger$ & $S M R$ & Obs & Exp & $S M R$ \\
\hline All causes (001-999) & 68 & $72 \cdot 0$ & 94 & 57 & $57 \cdot 2$ & 100 & 3 & 0.7 & 407 & 0 & 0.8 & 0 \\
\hline $\begin{array}{l}\text { All malignant neoplasms }(140-209) \text { : } \\
\text { Cancer of digestive organs }\end{array}$ & 17 & $14 \cdot 4$ & 118 & 12 & $12 \cdot 1$ & 99 & 0 & $0 \cdot 1$ & 0 & 0 & $0 \cdot 1$ & 0 \\
\hline and peritoneum $(150-159)$ & 1 & $3 \cdot 7$ & 27 & 4 & $3 \cdot 1$ & 128 & 0 & $0 \cdot 0$ & 0 & 0 & $0 \cdot 0$ & 0 \\
\hline $\begin{array}{l}\text { Cancer of respiratory system }(160-163) \\
\text { Cancer of brain and other nervous system }\end{array}$ & 6 & $5 \cdot 1$ & 118 & 5 & $4 \cdot 5$ & 112 & 0 & $0 \cdot 0$ & 0 & 0 & $0 \cdot 1$ & 0 \\
\hline $\begin{array}{l}\text { Cancer of brain and other nervous system } \\
(191,192)\end{array}$ & ${ }^{n}{ }_{0}$ & $0 \cdot 6$ & 0 & 0 & 0.5 & 0 & 0 & $0 \cdot 0$ & 0 & 0 & 0.0 & 0 \\
\hline All lymphopoietic cancer $(200-208)$ & 5 & 1.6 & $312^{*}$ & 0 & 1.2 & 0 & 0 & 0.0 & 0 & 0 & 0.0 & 0 \\
\hline Cancer of ill defined sites (199) & 4 & 1.0 & $388^{*}$ & 2 & $0 . \overline{9}$ & 229 & 0 & $0 \cdot 0$ & 0 & 0 & 0.0 & 0 \\
\hline Arteriosclerotic heart disease $(410-413)$ & 25 & $23 \cdot 0$ & 109 & 17 & $19 \cdot 5$ & 87 & 1 & $0 \cdot 1$ & 764 & 0 & $0 \cdot 2$ & 0 \\
\hline All vascular lesions of CNS $(430-438)$ & 3 & 3.6 & 83 & 4 & $2 \cdot 8$ & 144 & 0 & 0.0 & 0 & 0 & $0 \cdot 0$ & 0 \\
\hline All accidents (E800-E949): & 8 & $8 \cdot 0$ & 100 & 8 & 4.9 & 163 & 1 & $0 \cdot 2$ & 554 & 0 & $0 \cdot 2$ & 0 \\
\hline Motor vehicle accidents (E810-E825) & 4 & $4 \cdot 3$ & 94 & 2 & $2 \cdot 4$ & 85 & 0 & 0.1 & 0 & 0 & $0 \cdot 1$ & 0 \\
\hline Suicide (E950-E959) & 1 & $2 \cdot 6$ & 38 & 1 & $1 \cdot 7$ & 60 & 0 & $0 \cdot 1$ & 0 & 0 & $0 \cdot 1$ & 0 \\
\hline
\end{tabular}

*Statistically significant at $\alpha=0.05$.

+Employees may have worked in more than one area and as a consequence may be counted multiple times in the table.

† Expected deaths based on United States white male mortality rates.

Table 8 Observed and expected* mortality from all malignant neoplasms by years of 2,4-D exposure and interval since first exposure

\begin{tabular}{|c|c|c|c|c|c|c|}
\hline \multirow[b]{2}{*}{ Years of exposure } & \multicolumn{6}{|c|}{ Interval since first exposure } \\
\hline & $0-$ & $1-$ & $5-$ & $15-$ & $25-$ & Total \\
\hline $\begin{array}{c}0- \\
1- \\
5- \\
15- \\
25-\end{array}$ & $0 / 0 \cdot 2$ & $\begin{array}{l}0 / 0 \cdot 6 \\
3 / 0 \cdot 8\end{array}$ & $\begin{array}{l}2 / 2 \cdot 1 \\
1 / 1 \cdot 3 \\
0 / 1 \cdot 0\end{array}$ & $\begin{array}{l}4 / 2 \cdot 9 \\
1 / 2 \cdot 2 \\
1 / 1 \cdot 1 \\
0 / 0 \cdot 7\end{array}$ & $\begin{array}{l}4 / 3.4 \\
4 / 4 \cdot 0 \\
3 / 1 \cdot 7 \\
2 / 0 \cdot 5 \\
1 / 0.4\end{array}$ & $\begin{array}{r}10 / 9 \cdot 2 \\
9 / 8 \cdot 3 \\
4 / 3 \cdot 8 \\
2 / 1 \cdot 2 \\
1 / 0 \cdot 4\end{array}$ \\
\hline Total & $0 / 0 \cdot 2$ & $3 / 1 \cdot 4$ & $3 / 4 \cdot 4$ & $6 / 6.9$ & $14 / 10 \cdot 0$ & $26 / 22 \cdot 9$ \\
\hline
\end{tabular}

*Expected deaths based on United States white male mortality rates. 
Table 9 Mortality summary by cumulative dose of 2,4-D exposure

\begin{tabular}{|c|c|c|c|c|c|c|c|}
\hline \multirow[b]{3}{*}{ Cause of death (ICDA-8) } & \multirow{3}{*}{$\begin{array}{l}\text { Cumulative } \\
\text { dose* }\end{array}$} & \multicolumn{6}{|c|}{ Exposure lagged } \\
\hline & & \multicolumn{3}{|c|}{0 years } & \multicolumn{3}{|c|}{15 years } \\
\hline & & Obs & Exp $†$ & $S M R$ & Obs & $\operatorname{Exp}$ & $S M R$ \\
\hline All causes (001-999) & $\begin{array}{l}\text { Low } \\
\text { Moderate } \\
\text { High }\end{array}$ & $\begin{array}{l}33 \\
32 \\
46\end{array}$ & $\begin{array}{l}34 \cdot 3 \\
32 \cdot 5 \\
44 \cdot 2\end{array}$ & $\begin{array}{r}96 \\
98 \\
104\end{array}$ & $\begin{array}{l}21 \\
25 \\
33\end{array}$ & $\begin{array}{l}17 \cdot 8 \\
22 \cdot 6 \\
33 \cdot 2\end{array}$ & $\begin{array}{r}118 \\
111 \\
99\end{array}$ \\
\hline All cancer (140-209): & $\begin{array}{l}\text { Low } \\
\text { Moderate } \\
\text { High }\end{array}$ & $\begin{array}{r}5 \\
10 \\
11\end{array}$ & $\begin{array}{l}6 \cdot 4 \\
6 \cdot 6 \\
9 \cdot 6\end{array}$ & $\begin{array}{r}78 \\
151 \\
115\end{array}$ & $\begin{array}{l}4 \\
7 \\
9\end{array}$ & $\begin{array}{l}4 \cdot 0 \\
5 \cdot 2 \\
7 \cdot 7\end{array}$ & $\begin{array}{l}101 \\
135 \\
116\end{array}$ \\
\hline Digestive cancer $(150-159)$ & $\begin{array}{l}\text { Low } \\
\text { Moderate } \\
\text { High }\end{array}$ & $\begin{array}{l}1 \\
3 \\
1\end{array}$ & $\begin{array}{l}1.6 \\
1.7 \\
2.5\end{array}$ & $\begin{array}{r}63 \\
177 \\
41\end{array}$ & $\begin{array}{l}2 \\
2 \\
1\end{array}$ & $\begin{array}{l}1.0 \\
1.3 \\
2.0\end{array}$ & $\begin{array}{r}199 \\
151 \\
51\end{array}$ \\
\hline Respiratory cancer $(160-163)$ & $\begin{array}{l}\text { Low } \\
\text { Moderate } \\
\text { High }\end{array}$ & $\begin{array}{l}2 \\
2 \\
5\end{array}$ & $\begin{array}{l}2 \cdot 2 \\
2 \cdot 4 \\
3 \cdot 6\end{array}$ & $\begin{array}{r}91 \\
84 \\
140\end{array}$ & $\begin{array}{l}1 \\
2 \\
5\end{array}$ & $\begin{array}{l}1 \cdot 5 \\
2 \cdot 0 \\
3 \cdot 0\end{array}$ & $\begin{array}{r}67 \\
100 \\
165\end{array}$ \\
\hline $\begin{array}{l}\text { Cancer of brain and other nervous system } \\
(191,192)\end{array}$ & $\begin{array}{l}\text { Low } \\
\text { Moderate } \\
\text { High }\end{array}$ & $\begin{array}{l}0 \\
0 \\
0\end{array}$ & $\begin{array}{l}0 \cdot 3 \\
0 \cdot 3 \\
0 \cdot 3\end{array}$ & $\begin{array}{l}- \\
- \\
-\end{array}$ & $\begin{array}{l}0 \\
0 \\
0\end{array}$ & $\begin{array}{l}0 \cdot 1 \\
0 \cdot 2 \\
0 \cdot 2\end{array}$ & $\begin{array}{l}- \\
- \\
--\end{array}$ \\
\hline All lymphopoietic cancer (200-209) & $\begin{array}{l}\text { Low } \\
\text { Moderate } \\
\text { High }\end{array}$ & $\begin{array}{l}1 \\
3 \\
1\end{array}$ & $\begin{array}{l}0.8 \\
0 \cdot 7 \\
1.0\end{array}$ & $\begin{array}{l}125 \\
417 \\
105\end{array}$ & $\begin{array}{l}1 \\
1\end{array}$ & $\begin{array}{l}0.4 \\
0.5 \\
0.7\end{array}$ & $\begin{array}{l}268 \\
211 \\
145\end{array}$ \\
\hline Cancer of ill defined sites (199) & $\begin{array}{l}\text { Low } \\
\text { Moderate } \\
\text { High }\end{array}$ & $\begin{array}{l}1 \\
2 \\
2\end{array}$ & $\begin{array}{l}0.5 \\
0.5 \\
0.7\end{array}$ & $\begin{array}{l}213 \\
418 \\
292\end{array}$ & $\begin{array}{l}0 \\
2 \\
2\end{array}$ & $\begin{array}{l}0.3 \\
0 \cdot 4 \\
0.6\end{array}$ & $\begin{array}{l}\overline{540} \\
359\end{array}$ \\
\hline Diseases of circulatory system (390-458) & $\begin{array}{l}\text { Low } \\
\text { Moderate } \\
\text { High }\end{array}$ & $\begin{array}{l}15 \\
14 \\
24\end{array}$ & $\begin{array}{l}13.9 \\
14.8 \\
21.3\end{array}$ & $\begin{array}{r}108 \\
95 \\
113\end{array}$ & $\begin{array}{l}13 \\
14 \\
17\end{array}$ & $\begin{array}{r}8.8 \\
11.4 \\
16.8\end{array}$ & $\begin{array}{l}147 \\
123 \\
101\end{array}$ \\
\hline
\end{tabular}

${ }^{*}$ Low $=<0.5 \mathrm{mg} / \mathrm{m}^{3}$-yrs; moderate $=0.5-4.9 \mathrm{mg} / \mathrm{m}^{3}$-yrs; and high $=\geq 5 \mathrm{mg} / \mathrm{m}^{3}$-yrs

Dose $=\sum_{i}^{N} d_{1} \cdot$ TWA $_{i}$ where $d_{i}=$ the number of years worked in the $i$ th job, and TWA $=$ representative time weighted average exposure value for $i$ th job.

† Expected deaths based on United States while male mortality rates.

and $\geq 5.0 \mathrm{mg} / \mathrm{m}^{3}$-years. Analyses were done first lagging exposure zero years and then 15 years to allow for possible expression of a latency period. There were no significant mortality trends for any of the causes of death evaluated.

\section{Discussion}

Cause specific mortality has been reported up to the end of 1982 for 878 workers exposed to 2,4-D during its manufacture, formulation, or packaging. The principal hypothesis was that brain neoplasms might be raised since a recently completed chronic toxicity oncogenicity study in rats had suggested a link with 2,4-D exposure at high doses. No deaths from brain neoplasms were observed among the 111 deaths occurring in this cohort. The relatively small population size and limited duration of follow up for many workers restricted the power of the study somewhat. Nevertheless, a major increase (more than fivefold) in brain cancer can effectively be ruled out. When these data are taken together with data reported on other populations exposed to 2,4-D, the evidence against an increased risk of brain cancer in man is more persuasive. Lynge surveyed the incidence of cancer among 4459 workers in Denmark who had manufactured phenoxy herbicides, including 2,4-D, before 1982. ${ }^{9}$ Six brain cancers were reported among all male and female workers versus 7.39 expected $(95 \% \mathrm{CI}=$ 30-177). Studies of agricultural, forestry, and other workers potentially exposed to 2,4-D, although not reporting specific expected numbers of brain cancers, did not report brain cancers as having occurred in excess. ${ }^{10-13}$

In the present study mortality among cohort members from all causes combined was equal to expected levels based on a comparison with United States men and was raised slightly relative to unexposed workers from this manufacturing location, although the difference was not statistically significant. The apparently higher mortality was due to small, nonsignificant rises in total cancer, diseases of the circulatory system, and accidents not involving moior vehicles. None of those causes of death, however, showed relations with duration or cumulative dose of 2,4-D exposure.

A significant excess of deaths from cancer of other and unspecified sites was noted in the cohort relative to United States men. Although mortality from ill defined cancer tends to be higher in general among 
employees from this location,' it remained excessive among exposed relative to unexposed workers. There was no evidence of a significant relation between the risk of death from ill defined cancer and either duration or cumulative dose of 2,4-D exposure. Lacking further information about the specific nature of these cancers, nothing more can be concluded about them.

Several studies of people exposed to 2,4-D and other phenoxy herbicides have suggested an increased risk of soft tissue sarcoma (STS), ${ }^{914}$ although other studies have failed to show such an association. ${ }^{16-20}$ All death certificates were reviewed from the present study with specific attention directed at STS and no evidence of any cases of STS was found.

Data from several studies suggest that agricultural workers may be at increased risk of malignant lymphoma ${ }^{21-23}$ and although two studies suggest a link with the use of phenoxy herbicides, ${ }^{20} 24$ other studies of groups exposed to phenoxy herbicides do not support this. ${ }^{161925}$ Two deaths from non-Hodgkin's lymphoma occurred in the present study. Both were among the subset of workers with the potential for additional exposures to TCDD or H/OCDDs or both. Death certificates listed one of the cases as a generalised lymphosarcoma, whereas the other was indicated to have been a reticulum cell sarcoma. Each case was estimated to have accumulated a moderate career 2,4-D dosage ( $<5.0 \mathrm{mg} / \mathrm{m}^{3}$-years). The relatively short interval between first exposure and death for each of those cases (3.0 and 10.5 years, respectively) also must be considered. Occupational carcinogens usually act only after a latency period exceeding 15 or more years. ${ }^{26}$

In summary, this study does not support a cause effect relation between 2,4-D exposure and mortality from all causes, total malignant neoplasms, or any specific cancer including brain cancer.

We gratefully acknowledge the technical contributions of K M Bodner, G A Chateauneuf, J B Cartmill, and $\mathrm{K} T$ Wymer, and clerical help from $M L$ Trumbell and A A Grzegorczyk.

\section{References}

1 Bond GG, McLaren EA, Cartmill JB, et al. Cause specific mortality among male chemical workers. Am J Ind Med 1987;12:353-84.

2 Enterline PE, Marsh GM. Cancer among workers exposed to arsenic and other substances in a copper smelter. $\mathrm{Am} J$ Epidemiol 1983;116:895-911.

3 Monson RR. Analysis of relative survival and proportional mortality. Computers and Biomedical Research 1974;7:325-32.
4 Miettinen OS. Estimability and estimation in case-referent studies. Am J Epidemiol 1976;103:226-35.

5 Fisher RA. Statistical methods and scientific inference. London: Oliver and Boyd, 1956.

6 Breslow NE, Lubin JH, Marek P, Langholtz B. Multiplicative models and the analysis of cohort data. Journal of the American Statistical Association 1983;78:1-12.

7 Hakulinen T. A Mantel-Haenszel statistic for testing the association between polychotomous exposure and a rare outcome. Am $J$ Epidemiol 1981;113:192-6.

8 Bond GG, McLaren EA, Baldwin CL, Cook RR. An update of mortality among chemical workers exposed to benzene. Br J Ind Med 1986;43:685-91.

9 Lj'nge E. A follow-up study of cancer incidence among workers in manufacture of phenoxy herbicides in Denmark. $\mathrm{Br} J$ Cancer 1985;52:259-70.

10 Axelson O, Sundell L, Anderson K, et al. Herbicide exposure and tumor mortality. Scand J Work Environ Health 1980;6:73-9.

11 Hogstedt C. Westerlund B. Cohort study of mortality among forestry workers with and without exposure for phenoxy herbicides. Laektidn 1980;77:1828-31. (In Swedish).

12 Barthel E. Increased risk of lung cancer in pesticide exposed male agricultural workers. J Toxicol Environ Health 1981;8:1027-40.

13 Riihimaeki V, Asp S, Hernberg S. Mortality of 2,4-dichlorophenoxyacetic acid and 2,4,5-trichlorophenoxyacetic acid herbicide applicators in Finland. Scand J Work Environ Health 1982;8: $37-42$.

14 Hardell L, Sandstrom A. Case-control study: soft-tissue sarcomas and exposure to phenoxyacetic acids or chlorophenols. $\mathrm{Br} \mathrm{J}$ Cancer 1979;39:711-7.

15 Ericksson M, Hardell L, Berg NO, et al. Soft-tissue sarcoma and exposure to chemical substances: a case-referent study. $\mathrm{Br}$ J Ind Med 1981;38:27-33.

16 Riihimaeki V, Asp S, Pukkala E, Hernberg S. Mortality and cancer mobidity among chlorinated phenoxyacid applicators in Finland. Chemosphere 1983;12:779-84.

17 Smith AH, Pearce NE, Fisher DO, et al. Soft-tissue sarcoma and exposure to phenoxyherbicides and chlorophenols in New Zealand. JNCI 1984;73:1111-7.

18 Wiklund K, Holm LE. Soft-tissue sarcoma risk in Swedish agricultural and forestry workers. $J N C I$ 1986;76:229-34.

19 Woods JS, Polissar L, Severson RK, Heuser L, Kulander BG. Soft tissue sarcoma and non-Hodgkin's lymphoma in relation to phenoxy herbicide and chlorinated phenol exposure in Western Washington. JNCI 1987;78:899-910.

20 Hoar SK, Blair A, Holmes FF, et al. Agricultural herbicide use and risk of lymphoma and soft-tissue sarcoma. JAMA 1986;256: $1141-7$

21 Cantor KP. Farming and mortality from non-Hodgkin's lymphoma: a case-control study. Int J Cancer 1982;29:239-47.

22 Burmeister LF, Everett GD, Vanlier SF, et al. Selected cancer mortality and farm practices in Iowa. Am J Epidemiol 1983;118: 72-7.

23 Buesching DP, Wollstadt L. Cancer mortality among farmers. JNCI 1984;72:503-4

24 Hardell L, Eriksson M, Lenner P, et al. Malignant lymphoma and exposure to chemicals, especially organic solvents, chlorophenols and phenoxy acids: a case-control study. $B r J$ Cancer 1981:43:169-76.

25 Pearce NE, Smith AH, Howard JR, et al. Non-Hodgkin's lymphoma and exposure to phenoxyherbicides, chlorophenols, fencing work, and meat works employment: a case-control study. Br J Ind Med 1986;43:75-83.

26 Doll R. Occupational cancer: a hazard for epidemiologists. Int J Epidemiol 1985;14:22-31. 